\title{
Colonization of synthetic sponges at the deep-sea Lucky Strike hydrothermal vent field (Mid-Atlantic Ridge): a first insight
}

\author{
Baldrighi Elisa ${ }^{1,{ }^{*}}$, Zeppilli Daniela ${ }^{1}$, Crespin Rosalie ${ }^{1}$, Chauvaud Pierre ${ }^{1}$, Pradillon Florence ${ }^{1}$, \\ Sarrazin Jozée ${ }^{1}$
}

${ }^{1}$ IFREMER, Centre Brest, REM/EEP/LEP, ZI de la pointe du diable, CS10070Plouzané, France

*Corresponding author : Elisa Baldrighi, email address : Elisa.Baldrighi@ifremer.fr

\begin{abstract}
:
The main objective of the present study was to investigate invertebrate colonization processes at deepsea hydrothermal vents in response to environmental factors and to the presence of complex artificial substrata (i.e., synthetic sponges). We set out a pilot experiment at $1700 \mathrm{~m}$ depth on the Lucky Strike vent field (Eiffel Tower, Mid-Atlantic Ridge). Synthetic sponges were deployed in 2011 at five sites along a gradient of hydrothermal activity and were recovered in 2013, and the composition of macro- and meiofauna was assessed on four of them. The influence of temperature and fluid inputs on colonizer faunal abundance and diversity was analyzed. Faunal abundance and diversity decreased with increasing distance from vent emission. The colonizers were represented by a subset of species characterizing the natural populations at the Eiffel Tower edifice. Some taxa (e.g., pycnogonids, ophiuroids, cnidarians, foraminiferans) represented new records not yet found on deployed substrata on the Eiffel Tower. Synthetic sponges harbored a high percentage (from $17.5 \%$ to $55 \%$ ) of juveniles and larval stages of polychaetes, molluscs, and copepods. A mature nematode community (mainly Cephalochaetosoma and Halomonhystera) in a reproductive stage was found. Variability in faunal composition was significantly correlated with distance from fluid emission. We hypothesize that the complex structure of inorganic sponge substrata may have favored settlement of juveniles and larvae. Sponge substrata may, therefore, help sample a wider range of organisms than other substrata, and, thereby, provide a more complete picture of vent biodiversity. The results provided in this study might improve our understanding of mechanisms that govern faunal colonization processes at vents.
\end{abstract}

Keywords : Synthetic sponges, Colonization, Lucky Strike, Meiofauna, Macrofauna, Substratum type 


\section{Introduction}

Hydrothermal vents (HVs) are hot spots of high productivity and biomass when compared to the surrounding deep-sea benthos (Tunnicliffe 1991; Van Dover et al. 2002). As vent fluid emissions are transient, hydrothermal sites have ephemeral lifespans ranging from years (e.g. the East Pacific Rise (EPR); Lutz et al. 2008) to decades or centuries (e.g., the Mid-Atlantic Ridge, (MAR); Humphris et al. 2002). Vents are patchily distributed and isolated from each other with large differences in spatial frequency of venting between ocean ridges (Beaulieu et al. 2015). On fast spreading ridges like the East Pacific Rise (EPR), characterized by frequent eruptions (Shank et al. 1998), vents are generally separated by a few kilometres (Tolstoy et al. 2006). Conversely, on slow spreading ridges (e.g. Mid-Atlantic Ridge, MAR), vent sites are more distant from each other (i.e. 100-350 kilometres; Beaulieu et al. 2013). In the Pacific, even when the nearest populated HV is situated several kilometres away (Marcus et al. 2009), nascent vent sites appear to be rapidly (months/years) colonized by vent organisms issued from a pool of regional species (Tunnicliffe et al. 1997; Mullineaux et al. 2010; Gollner et al. 2013). As in most ecosystems, colonization processes are intimately linked to reproduction, larval dispersal and recruitment as well as to immigration from surrounding environments (Gaudron et al. 2010), data for which there are still major knowledge gaps. Moreover, biological interactions between vent colonizers contribute to determine and maintain the composition and diversity of hydrothermal communities (Govenar and Fisher, 2007 and literature therein). Shank et al. (1998) suggested that successful vent faunal colonization may be strongly influenced by physical oceanographic processes and hydrothermal conditions, and also by temporal changes in geochemical composition of fluid emissions. In addition to the influence of fluid chemistry, the modification of substrata by microbial alteration or a preceding faunal species is an important mechanism that influence the colonization by a succession of species (Shank et al. 1998). However, our knowledge of colonization processes in the vent environment is still limited since natural recolonization observations are restricted to the 
Pacific Ocean were major volcanic eruptions lead to the formation of new colonization areas. At more temporally stable vent sites (MAR for example, Cuvelier et al. 2011), other means have to be found to gain insights about recruitment dynamics.

Over the last decades, several colonization experiments have been used to help identifying the factors that influence the recruitment and settling of species in the vent environments. These studies focused on the deployment of substrata, using a variety of experimental designs, substratum types (i.e. organic and inorganic) and durations (e.g. from months to years). There were done mainly on the EPR (East Pacific Rise; Govenar and Fisher 2007; Gollner et al. 2013, 2015), on Juan de Fuca Ridge (northeast Pacific; Kelly and Metaxas 2008) and along the MAR (Gaudron et al. 2010; Ivanenko et al. 2011; Cuvelier et al. 2014; Zeppilli et al. 2015; Plum et al. 2016). On EPR and Juan de Fuca Ridge, the type of substratum and their structural complexity heavily influenced the vent faunal colonization in term of abundance and diversity (Govenar and Fisher 2007, Kelly and Metaxas 2008). In the Govenar and Fisher (2007) case study, artificial tube worms were deployed along a chemosynthetic primary productivity gradient including areas in which $R$. pachyptila does not occur. The authors demonstrated that complex physical structures could support the highest colonizers' density and diversity in areas of high chemosynthetic primary production. Moreover, a similar species richness was reported between natural aggregations of $R$. pachyptila and artificial aggregations in intermediate- and high-productivity zones, suggesting that complex physical structure alone can support local species diversity in active venting areas. On the MAR, colonization experiments on different organic and inorganic substrata have shown that after two years, the environmental conditions rather than the type of substratum were the most important factors influencing the settlement and colonization of fauna (Ivanenko et al. 2011; Cuvelier et al. 2014; Plum et al. 2016). In contrast, the same experimental design showed that after 9 months, the density and composition of colonising nematodes were rather significantly influenced by the type of substratum (Zeppilli et al. 2015). Differences in conclusions from these studies emphasized the fact that deployment duration is an important factor to consider when examining colonization processes. 
In addition, to abiotic and biotic factors, habitat complexity, including habitat provision by other species, is known to play a key role in facilitating species abundance and diversity (Hull 1997; Bertness et al. 1999). Complex habitats contribute to increase the area available for settlement, benefit the retention of propagules (Eckman 1987; Tsurumi and Tunnicliffe 2003) and create a variety of microhabitats that favour species interactions (Kelly and Metaxas 2008). Moreover, the provision of space may also offer protection from predators and contribute to the concentration of food resources (Van Dover 2002; Govenar et al. 2005; Govenar and Fisher 2007).

In the present study, we continue the examination of factors that influence colonization processes on a particular substratum (artificial sponge) as part of a larger integrative study that was initiated in 2006 (Cuvelier et al. 2014) and it is still on-going. The overall objective of this global study is to better understand colonization processes at deep-sea hydrothermal vents in response to environmental factors such as temperature, fluid flow and the presence/structure of different substrata. This was experimentally assessed by using different types of substrata (wood, bones, slates and sponges) that were deployed along a gradient of venting activity in the vicinity of the Eiffel Tower edifice at $1700 \mathrm{~m}$ depth on the Lucky Strike vent field located on the Mid-Atlantic Ridge (MAR). The results presented here concern only those obtained on the sponges between 2011 and 2013. We first examined the abundance and diversity of faunal assemblages, i.e. meio- and macrofaunal compartments, found on synthetic sponges after a two-year deployment time and we explored the relation between estimated environmental conditions (temperature, fluid inputs) and faunal abundance and diversity. In the discussion, we compared our results with those obtained in preliminary and on-going experiments. Although the absence of duplication limits our conclusions, this study presents a first insight about how a complex 3D structure, not directly deployed on the seafloor, may influence colonization processes in the vicinity of vents.

\section{Material and methods}




\subsection{Study site}

The Lucky Strike vent field is located on the MAR, south of the Azores $\left(37^{\circ} 17.5^{\prime} \mathrm{N}, 32^{\circ} .16^{\prime} \mathrm{W}\right.$; Fig. 1). This vent field is characterized by the presence of multiple sulphide edifices located around a fossilized lava lake, at a mean depth of 1700 m (Ondréas et al. 2009). The 11-m high Eiffel Tower is a well-defined active edifice located south-east of the lava lake. Hydrothermal activity on the structure occurs through black smokers, flanges or diffusion zones (Cuvelier et al. 2009) and the temperatures of the focused emissions can reach $324^{\circ} \mathrm{C}$ (Charlou et al. 2000). The entire edifice is colonized by different faunal assemblages that were characterised by a series of ecological studies (Cuvelier et al. 2009; Cuvelier et al. 2011a; Sarrazin et al. 2015; Husson et al. 2016). Out of the six assemblages characterised by Cuvelier et al. (2009), five are visually dominated by mussels, differing in size and in the presence or absence of microbial mats. These assemblages colonise a narrow range of low temperature habitats, ranging from $4.8^{\circ} \mathrm{C}$ to $8.8^{\circ} \mathrm{C}$ in the mussels (Sarrazin et al. 2015). A sixth assemblage is composed of shrimp, mainly Mirocaris fortunata that inhabit warmer habitats, with temperature reaching up to $9.5^{\circ} \mathrm{C}$ (Cuvelier et al. 2011a). The diversity varies strongly along the fluid mixing gradient, with higher densities and species richness observed in low temperature habitats (Sarrazin et al. 2015). Since 2006, a series of colonization experiments were deployed on and around this edifice (Cuvelier et al. 2014, Zeppilli et al. 2015; Plum et al. 2016). The results presented here represent only a snap-shot of the experiment done between 2011 and 2013. Data on copepods from the same experiment but on the other substrata (slate, wood, bones) are presented in Plum et al. (2016).

\subsection{Experimental set-up}

Five single substrata (slate, wood, cow and pig bone, sponge) were deployed during the Momarsat 2011 cruise at five sites ( 1 to 5) located along a gradient of hydrothermal activity, representing a single sponge substratum per site. These sites were selected in previous experiments (Cuvelier et al. 
6

2014; Zeppilli et al. 2015; Plum et al. 2016, Fig. 1), allowing for the characterization of the activity gradient between the sites. Site 1 was the least active area located at the base of the edifice (low fluid input). Site 2 (high emission) was the most active area among the selected sites. It is located on the north-west side of the Eiffel Tower on top of the edifice. This site harboured the denser assemblages of Bathymodiolus azoricus mussels. The substrata at site 3 (intermediate emission) were placed near a crack with diffuse fluid flow characterized by the presence of a low abundance of Bathymodiolus azoricus surrounded by microbial mats. Site 4 (inactive) was located $25 \mathrm{~m}$ from two active edifices (Eiffel Tower \& Montsegur) and was chosen as an external site with limited hydrothermal input. A fifth site, located away from any hydrothermal influence was added to the previous colonization experiments (see site 5, Fig. 1). This new site 5 (external) is situated in the lava lake and characterized by the absence of detectable hydrothermal influence (Table 1). To facilitate deployment and recovery, the synthetic sponges were tied by a $\sim 15 \mathrm{~cm}$ long nylon rope to the wood substrata (Fig. 1). The latter was equipped with an autonomous temperature probe (HOBO U12-015-02, Onset), which recorded the local temperature on each site (as a proxy of hydrothermal activity) at $15 \mathrm{~min}$ intervals during the entire deployment period. The synthetic sponges (namely E1 to E5) are similar to those used in the shower (mesh bath sponges). They are made in polyethylene, a chemically resistant thermoplastic that can be very durable. These sponges are characterized by the presence of numerous holes of $\sim 1 \mathrm{~mm}$ diameter, creating a net forming convolution. The estimated planar colonization surface of each sponge is approximately $0.455 \mathrm{~m}^{2}$. Before 2011 , no sponges were deployed on the Eiffel Tower colonization experiment. The idea behind deploying these sponges was to offer a complex 3D substratum to the colonizing fauna and also a substratum that was not directly laid on the rock substratum as the others but rather floating at approximately $\sim 50 \mathrm{~cm}$ from the seafloor. We postulated that our chance to trap larvae was increased in comparison with the other type of substratum and also, that the complex structure of the sponge would offer better protection against predators and a more suitable habitat for smaller organisms. The results presented here concern only those found on the sponges. All 2011 substrata were recovered during 

20

the BIOBAZ 2013 cruise with the Remotely Operative Vehicle (ROV) Victor6000. A few substrata were loss, including a bone from site 5 and the sponge from site 1 (E1) that was lost during recovery. This study is based on data available from 4 (sites 2-5) of the 5 initial sites.

\subsection{Evaluation of environmental conditions}

In our dataset, the highest temperature $\left(7.3 \pm 1.6^{\circ} \mathrm{C}\right)$ was found at site 2 which is concordantly the site with the highest fluid inputs. Site 3 was characterized by intermediate temperatures $(5.5 \pm$ $0.6^{\circ} \mathrm{C}$ ) while the inactive site 4 and external site 5 were characterized by the lowest temperatures $\left(4.7 \pm 0.1^{\circ} \mathrm{C}\right.$ and $4.3 \pm 0.1^{\circ} \mathrm{C}$, respectively), representing low to no hydrothermal influence (Table 1). Mean temperature values reported in the present study (2011-2013) fell in the range of temperatures reported in previous experimental studies conducted between 2006 and 2011 and characterizing the investigated sites (Cuvelier et al. 2014; Zeppilli et al. 2015). Previous studies have demonstrated that temperature at the Lucky Strike vent field is a valuable proxy of the chemical characteristics of vent fluids (Sarradin et al. 2009). For instance, temperature correlates positively with total dissolved sulphide and iron concentrations (De Busserolles et al. 2009). Fluid input can also be estimated using the formula proposed by Sarradin et al. (2009): \%=0.314*T-1.38, calculated with the Eiffel Tower end-member temperature of $324^{\circ} \mathrm{C}$ reported in Charlou et al. (2000) and ambient temperature of $4.4^{\circ} \mathrm{C}$. Indeed, fluid inputs are very low in diffuse flow areas, varying from $0.9 \%$ at our most active site 2 to $0.05 \%$ at the external site (Plum et al. 2016; Table 1).

\subsection{Sample processing}

Upon recovery, all substrata were put in a thermally insulated sampling box and brought to the surface. On board, macrofauna (organisms retained on a $250 \mu \mathrm{m}$ mesh) was sorted and separated into major taxa. The rinse-off of each substratum was put into separate flasks. Half of the samples 
were fixed in buffered seawater formalin (4\%) and the other half was preserved in $96^{\circ}$ ethanol. In the laboratory, samples were analysed in details and passed over $250 \mu \mathrm{m}$ and $20 \mu \mathrm{m}$ sieves to separate the macrofaunal from the meiofaunal fraction. The limit of $250 \mu \mathrm{m}$ and $20 \mu \mathrm{m}$ for separating the faunal pool into macrofaunal and meiofaunal size classes were chosen in order to easily compare our results with previous studies (Cuvelier et al. 2014; Sarrazin et al. 2015; Zeppilli et al. 2015; Plum et al. 2016). In particular, the use of a $20 \mu \mathrm{m}$ sieve for deep-sea meiofaunal fraction is recommended to avoid underestimation of biodiversity (Sarrazin et al. 2015). Juveniles of macrofauna found in the meiofaunal fraction were considered as temporary meiofauna. All faunal organisms retained on the sieves were identified under a Leica Wild 10 stereomicroscope. For nematode identification, 150 randomly collected individuals were mounted on slides after formalin-ethanol-glycerol treatment. They were identified to the genus level according to Platt and Warwick (1983, 1988), Warwick et al. (1998), and the recent literature dealing with new nematode genera and species from the Atlantic Ocean (NeMys database, Deprez et al. 2005). Different faunal morphotypes and/or unknown species were reported as sp1, sp2, etc. Furthermore, a colonization rate index $(\mathrm{CI})$ was calculated by dividing the average number of colonists (per $\mathrm{m}^{2}$ ) by the number of days the sponges stayed at the seafloor (as proposed in Cuvelier et al. 2014 and adapted from a recruitment rate index from Romey et al. 1991; Table 2).

\subsection{Statistical analyses}

Meio- and macrofaunal abundances were expressed as individuals $/ \mathrm{m}^{2}$ and reported in Table 2. Meio- and macrofaunal diversity was expressed as taxonomical richness (TR) and the rarefaction biodiversity indices for theoretical samples of $n=50$ and $n=100$ individuals were calculated. All indices were calculated using the PRIMER6 software (Plymouth Marine Laboratory, UK; Clarke, 1993). Larvae and nauplii were not included in the taxonomic richness or in other diversity indices. 
Due to the lack of replicate, statistical analyses were limited to a principal component analysis (PCA) and a non-parametric multivariate multiple regression analysis. The PCA, based on squareroot transformed data, was used to visualize between-sponge variations in meio- and macrofaunal composition (PRIMER6 software, Plymouth Marine Laboratory, UK; Clarke, 1993). The relationship between meiofaunal and macrofaunal abundance and diversity and environmental variables (temperature, fluid inputs) was evaluated with a non-parametric multivariate multiple regression analysis (DistLM: distance-based linear model) using the PERMANOVA + add-on package for PRIMER6 software (McArdle and Anderson 2001; Anderson et al. 2008). For total abundance and diversity indices, the Euclidean distance was used as a resemblance measure, whereas for species composition, the analysis was based on Bray-Curtis dissimilarities (with square-root transformed abundance data). Forward selection was carried out and the adjusted $\mathrm{R}^{2}$ was selected as the criterion to enable fitting of the best explanatory environmental variables in the model (Anderson et al. 2008). The results are provided as marginal and sequential tests. The marginal test revealed how much each variable explains individually, ignoring all other variables. Following the results of this test, a sequential test was performed which examined whether the addition of a particular variable contributes significantly to the explained variation (Anderson et al. 2008).

\section{Results}

\subsection{Faunal communities}

Taxonomic composition- A total of 35 faunal taxa colonized the sponges (Table 3). Among this, 19 taxa were found exclusively in the macrofaunal size class and 4 exclusively in the meiofaunal one (Table 4). The macrofauna was dominated by polychaetes with 10 taxa followed by gastropods (4 taxa), chelicerates (2 taxa), ophiuroids, mytilids and cnidarians (1 taxa each). In the meiofaunal, only nematodes (3 taxa) and one polychaete (Hesionidae sp. 1) were restricted to this fraction. 
Larvae of polychaete and bivalve settlers were found as well as numerous copepod nauplii (Table 3). Polychaetes, crustaceans, foraminiferans and cnidarians were found either on active or on inactive sites (Table 4). However, chelicerates, ophiuorids, mytilids and most gastropods were restricted to the substrata located at active and intermediate sites (2 and 3). No copepod nauplii and almost no nematodes were found on the substrata at inactive and external sites (4 and 5). With the exception of five polychaete taxa (Glyceridae sp. 2, Ophryotrocha sp., Hesionidae sp. 2 and sp. 3. Trichobranchidae undet.), only a few taxa (Lepetodrilus sp., Nematode undet.) appear to be exclusive to inactive sites (Table 4).

Density- The highest faunal density (175 818 ind. $/ \mathrm{m}^{2}$ ), including juveniles and nauplii, was found on substrate E2 (high emission) and the lowest was found at the inactive site E4 (532 ind. $\left./ \mathrm{m}^{2}\right)$ (Table 2 and Fig. 2). Overall, the abundance of organisms belonging to the meiofaunal size class decreased with the diminution of fluid emissions. With the exception of site 5 , the meiofaunal fraction dominated the total faunal abundance, varying from 166736 ind. $/ \mathrm{m}^{2}$ on E2 (high emission site) to 371 ind./ $\mathrm{m}^{2}$ on E4 (low hydrothermal influence) (Fig. 2). The density of organisms found in the macrofaunal size class showed a similar trend, varying from $9081 \mathrm{ind} . / \mathrm{m}^{2}$ on E2 to $160 \mathrm{ind} . / \mathrm{m}^{2}$ on E4 (Table 2). They showed a slight increase on site 5 (473 ind. $\left./ \mathrm{m}^{2}\right)$ (Fig. 2).

In more details (see also Tables 3 and 4), densities on E2 were dominated by Draconematidae nematodes (Cephalochaetosoma sp.) as well as by copepod nauplii and adults. The macrofaunal fraction was dominated by Dorvilleidae polychaetes. A similar result was reported on substratum E3 for the meiofaunal fraction but the macrofaunal fraction was rather dominated by Bathymodiolus azoricus and Protolira sp. gastropods. For external site 4, the meiofauna on E4 was dominated by bivalve settlers as well as by adult copepods and ostracods. The macrofaunal density was low with relatively few representatives of bigger size copepods, ostracods, nematodes, foraminifera and bivalve settlers. No polychaetes were present. On E5 (inactive site), the meiofauna was also dominated by adult copepods and ostracods as well as bivalve settlers. No nematodes were present. 

271 present.

For the macrofauna, 5 families of polychaetes as well as adult copepods and bivalve settlers were

Diversity- A higher total taxonomic richness was reported on the sponges located at the most active sites E2 and E3 (Table 5). However, the rarefaction diversity indices showed the highest value at the external site E5 (Table 5). Lower values in the rarefaction diversity indices at E2 and E3 can be explained by a dominance of nematodes, particularly of the genus Cephalochaetosoma (representing $61 \%$ and $32 \%$ of the total abundance at E2 and E3, respectively) and copepods (representing $25 \%$ and $13 \%$ of the total abundance at E3 and E2, respectively) at the most active sites.

Community structure- The structure of communities on the sponge substrata changed along the emission gradient (Fig. 3a). Nematodes, mostly represented by the genera Cephalochaetosoma, Halomonhystera and Oncholaimus, highly abundant $(>70 \%)$ at site E2, were replaced by crustaceans (i.e. especially copepods) away from the vent emission. At all sites, the densities of larvae and juveniles was remarkable, varying from a minimum of $127 \mathrm{ind} . / \mathrm{m}^{2}$ on E5 (representing $18 \%$ of the abundance) to a maximum of $49043 \mathrm{ind} . / \mathrm{m}^{2}$ on E3 (representing $55 \%$ of the abundance) (Fig. 3b). It included larvae of polychaetes and juveniles of nematodes (mostly Cephalochaetosoma and Halomonhystera), bivalve settlers as well as copepod nauplii and copepodid stages. Polychaetes had very low abundance on all substrata, except E5 where they represented 29\% of the total abundance. Macrofaunal fraction represented a low proportion $(\sim 5 \%)$ of the total faunal abundance at both active (E2) and intermediate (E3) sites, but increased its contribution at the inactive (E4, $30 \%$ of the total abundance) and external (E5, $65 \%$ of the total abundance) sites.

The PCA analysis showed that sponges situated at the high (E2) and intermediate (E3) emission sites were strongly separated from the other substrata (Fig. 4), revealing a discrimination between sponges near the vent emissions with those located away from hydrothermal activity. The presence of high densities of Cephalochaetosoma explains the separation of sponge E2 while the extremely 
high abundance of nauplii and copepods on both E2 and E3 sponges explained their separation from the substrata at other sites (E4 and E5).

Colonization index- The highest colonization index (CI) was found at the most active site E2, while lower values were found at the inactive and external sites (Table 2). Also, the meiofaunal CI was higher compared to that of the macrofauna, with the exception of substrata E5 where the macrofaunal CI was higher than that of meiofauna (Table 2).

\subsection{Links with environmental conditions}

Environmental variables are reported in Table 1. The DistLM analysis was performed to assess the influence of environmental variables on faunal descriptors (i.e. faunal abundance, diversity index and taxa composition). Results showed that changes in taxonomic composition were significantly correlated (66\%) by the position of sponges from the fluid emission (Table 6), as observed in Figure 5. No other significant correlations were found between the other environmental predictors (temperature, fluid inputs) and the abundance and diversity of fauna (Table 6).

\section{Discussion}

This pilot study showed preliminary results on deep-sea fauna (meio- and macrofaunal size classes) colonizing artificial sponges deployed in a gradient of environmental conditions in the vicinity of an active hydrothermal edifice on the Lucky Strike vent field (MAR). The role of environmental features on the composition, density and diversity of the recruited fauna was considered. The consideration of the meio- and macrofaunal size classes in our study differs from several others in which they are considered separately. This dual approach is fundamental since both size classes 
may have different life-histories linked to their different dispersal patterns (Warwick 1984; Gollner et al. 2015) and therefore, exhibit different colonization patterns.

\section{Insights on community composition and diversity}

The meiofaunal fraction was the most abundant fraction on the sponges, representing $70 \%$ to $95 \%$ of the total densities, with the exception of site 5 in which the macrofaunal fraction dominated (representing $65 \%$ of the total density). The dominance of meiofauna (copepods \& nematodes) was similar to that found in a previous study on natural faunal assemblages on the same edifice (Sarrazin et al. 2015) and on deployed artificial substrata (Cuvelier et al. 2014). Nematodes are known to be a widespread dominant taxon that can cope with many habitat conditions (Zekely et al. 2006; Copley et al. 2007; Vanreusel et al. 2010) and able to quickly (within months) colonize artificial substratum deployed at vents (Zeppilli et al., 2015). Two genera (Cephalochaetosoma and Halomonhystera) dominated at the high and intermediate emission sites. This corresponds to what was already reported at the Eiffel Tower both from colonization experiments (Cuvelier et al. 2014) and natural communities (Sarrazin et al. 2015), confirming the dominance of these two genera near the Eiffel Tower edifice. In this study however, nematodes were almost absent from the substrata found at the external sites. This result differed from our previous colonization studies in which they were represented along the hydrothermal gradient (Cuvelier et al. 2014; Zeppilli et al. 2015).

Hydrodynamic processes play a key role in species distribution and dispersal (Marsh et al., 2001). The colonization of sponges placed in the vicinity of vent fluids may have facilitated meiofaunal groups with less dispersal potential such as nematodes (Giere 2009), thanks to the transfer of organisms by local turbulence. Horizontal currents and fluid flux are known to affect faunal distribution and diversity in hydrothermal communities (Sarrazin et al. 2014, 2015) and several studies showed that, despite their limited active dispersal (Higgins and Thiel, 1988), nematodes were present in the water column, mainly suspended by water currents or bioturbation (Sibert, 1981; 
Palmer et al., 1988; Fonseca-Genevois et al. 2006). Moreover, Boeckner and co-authors (2009) showed that different meiofaunal taxa, including nematodes, are able to colonize substrata suspended at different distances (from $0.5 \mathrm{~m}$ to $3 \mathrm{~m}$ ) above the sea floor. In their study, very weak currents, along with the effect of tides, were sufficient to suspend and transport the meiofauna into the water column and enhance their dispersal (Boeckner et al. 2009). In our study, nematodes were apparently unable to settle on the sponges, located above the seafloor, in areas located away from hydrothermal activity. Weak hydrodynamic processes encountered away from vents may have limited their settling.

As frequently noted for hydrothermal vents, copepods were the second most abundant meiofaunal taxon after nematodes (Vanreusel at al. 1997; Zekely et al. 2006; Gollner et al. 2007). They can thrive in different hydrothermal microhabitats (Sarrazin et al. 2015) and are able to colonize different organic and inorganic substrata (Plum et al. 2016). Similarly to nematodes, copepods showed the higher abundances at the active sites but unlike them, they were still present, at lower densities, at the inactive and external sites. This pattern was opposite to that reported by Plum et al. (2016) in which copepod densities from wood and slate substrata tended to increase with decreasing fluid inputs. This observation seems to support that the coupling between the type of substratum and the gradient of fluid emission also has a role in affecting the density patterns of copepods (Plum et al. 2016).

The macrofaunal community composition on sponge substrata changed according to vent emissions and its abundance decreased at the inactive and external sites. The most represented macrofaunal taxa were those usually encountered at the Eiffel Tower vent site: the 'engineering' species $B$. azoricus, lepetodrilid gastropods and polychaetes (Cuvelier et al. 2009, Sarrazin et al. 2015) and reported also in a previous colonization study (Cuvelier et al. 2014). However, despite their abundance at Eiffel Tower, no shrimp were extracted from the sponges. This may represent a sampling bias as the shrimp are mobile and may have escaped during sponge recovery but it is also 
likely that the microhabitat they offer does not correspond to that of the shrimp which are found in the warmer habitats of Eiffel Tower (Sarrazin et al. 2015). Conversely, taxa such as ophiuroids and pycnogonids that were never reported from our other substrata (i.e. wood and slate; Cuvelier et al. 2014) were collected. We can hypothesize that the convolutions of the sponges acted like a trap for these taxa, as it was initially expected. These organisms, that are part of the natural Eiffel Tower fauna, are difficult to sample (Sarrazin et al. 2015), so the use of such heterogeneous substrata may offer a strategy for their collection. Indeed, the complex structure of synthetic sponges could represent a suitable habitat and their complexity may have favoured the presence of a unique faunal community (Zekeley et al. 2006) and increased the area available for settlement (Kelly and Metaxas 2008). Furthermore, in environments subjected to physical stress, habitat complexity could increase the frequency of positive interactions enhancing faunal diversity (Kelly and Metaxas 2008 and literature therein). Indeed, the presence of these taxa, new to the substrata (i.e. ophiuroids and pycnogonids), was detected only on the sponges deployed at the most active sites and subject to harsher environmental conditions. Sponges may also have been use as a protection against predators (Van Dover 2003; Govenar and Fisher 2007; Kelly and Metaxas 2008). Moreover, as stated for nematodes, ophiuroid and pycnogonid propagules could have taken advantage from the vicinity of vent fluids to colonize the synthetic sponges.

Gastropods (and few other groups) appear to be restricted to the active areas, while the polychaete community appears to shift from one group to the other. Indeed, no redundancy in the polychaete taxa between the sponges located at the active and inactive sites is observed as if there were two distinct communities. Indeed, some families such as Ampharetidae, Polynoidae and Spionidae are restricted to the venting areas. Others, such as Glyceridae, Dorvilleidae and Hesionidae have different morphotypes between the active and inactive ones. A better resolution in polychaete identification would help to describe these communities with more precision.

Even if the macrofauna found on synthetic sponges showed lower abundance values compared to the meiofauna, its diversity was almost twice that of the meiofauna, as observed in the natural Eiffel 
Tower communities (Sarrazin et al. 2015). Nevertheless, this result could change once copepods are identified at a lower taxonomic level, i.e. genus or species (see Plum et al. 2016), revealing a similar or even higher meiofaunal diversity when compared to the macrofaunal one. Taxonomic richness values on sponges were lower than those reported at the Eiffel Tower edifice (19 macrofaunal taxa versus 41 in Sarrazin et al. 2015) but similar to those found in our previous colonization experiment (20 macrofaunal taxa in Cuvelier et al. 2014).

A total of 35 faunal taxa colonized the sponges, representing $44 \%$ of the faunal richness identified at the Eiffel Tower edifice (79 meio- macrofaunal taxa; Husson et al. 2016). This was slightly higher than those found on inorganic sponges deployed on the Juan de Fuca vent site (30 taxa, Kelly and Metaxas 2008) and to those found on organic and inorganic substrata deployed at the Eiffel Tower edifice (Cuvelier et al. 2014). The repartition of macrofauna/meiofauna on the edifice shows that the number of taxa in the macrofauna dominates, representing $\sim 59 \%$ of the identified taxa (Sarrazin et al. 2015). The repartition macrofauna/meiofauna was approximately the same here (54\%), although we did not reach a similar taxonomic resolution. In particular, while 12 taxa of copepods were found in Eiffel Tower habitats (Sarrazin et al. 2015) and 45 on wood, slate and bone substrata from the same sampling sites (Plum et al. 2016), in the present study the copepods were only identified at the subclass level. This lack of taxonomic resolution leads to an underestimation of taxonomic richness, particularly in the meiofaunal compartment. Even if nematodes were identified at the lowest taxonomic level, only a low proportion of the natural vent nematode community was found on the sponges (4 taxa on sponges/15 taxa on Eiffel Tower in Husson et al. 2016).

\section{Influence of environmental conditions}

The community structure on the sponge substrata changed along the emission gradient. Half of the taxa were indifferently present on active or inactive sites. For the rest of the fauna, a similar 
proportions of taxonomic groups $(\sim 23 \%)$ were restricted either to areas influenced by hydrothermal activity or to those with little or no influence. For example, copepod nauplii and nematodes were restricted to the sponges from the active sites and over $35 \%$ of the polychaete taxa were only found on the sponges located outside the venting influence. Curiously, most of the bivalve settlers were found on the inactive sites. Whether they were representative of Bathymodiolus azoricus or of other bivalves remains to be resolved.

Four of the taxa (Bathymodiolus azoricus, Pseudorimula midatlantica, Lurifax vitreus and Cephalochaetosoma) found on our sponges are the indicator species of cold microhabitats at Eiffel Tower (Sarrazin et al. 2015). All these species were reported on synthetic sponges deployed at active and intermediate emission sites, in a range of temperature slightly higher than that of the cold microhabitats defined in Sarrazin et al. $\left(2015 ; 5.11 \pm 0.37^{\circ} \mathrm{C}\right)$. Similarly to our findings, Cuvelier et al. (2014) reported the four taxa mentioned above on their organic and inorganic substrata deployed at active sites at the Eiffel Tower. Overall, the colonizing taxa confined on synthetic sponges deployed at sites 2 and 3 (active sites) were those usually found at Eiffel Tower hydrothermal edifice e.g., gastropods L. atlanticus, P. midatlantica, L. vitreus and the bivalve B. azoricus; the nematode genera Cephalochetosoma, Halomonhystera and Oncholaimus; the polychaetes $B$. seepensis as well as representatives of the families Glyceridae, Ampharetidae and Spionidae (Cuvelier et al. 2014; Zeppilli et al. 2015). Other taxa such as: pycnogonids, ophiuroids, cnidarians, foraminiferans, the polychaete family Dorvilleidae and ostracods represented new records not found yet on deployed substrata on the Eiffel Tower. Some of them, such as pycnogonids and ophiuroids, are mainly visible on imagery (e.g. Cuvelier et al. 2014).

Among the few taxa (i.e. mainly polychaetes) confined on the sponges at inactive sites (4 and 5), only one was a new record. It has never been reported neither on deployed substrata, nor from natural populations from the Eiffel Tower vent: the Trichobranchidae polychaete family. The presence of this taxon has been already reported from a low temperature shallow water hydrothermal vent field in the North Atlantic Ocean (the Mohn's Ridge vent field; Schander et al. 
2010) and recognized by the authors as a non-typical vent taxon. This could explain its presence only at the inactive site.

The total faunal taxonomic richness decreased with distance from vent emissions (i.e. E2 $>$ E3 $>$ E5 $>$ E4), the inactive site exhibiting the lowest taxon number. Concerning the rarefaction diversity indices, the highest values were at the external site (i.e. E5 $>$ E2 $>$ E3 $>$ E4). This finding was not totally in line with what reported by Cuvelier et al. (2014) in which high densities but low diversity characterized the substrata at the most active sites. The highest faunal density was found on the sponge from the most active site while the lowest was found at the site with low hydrothermal influence (site 4). Both faunal size classes followed the same trend, exhibiting a slight increase on the sponge from site 5. This decreasing pattern of density with decreasing vent emissions was observed in most of our colonization studies at Eiffel Tower (Cuvelier et al. 2014, Zeppilli et al. 2015, present study). Indeed, a higher faunal abundance at the proximity of vent emissions is considered a typical feature of hydrothermal ecosystems (Tsurumi and Tunnicliffe 2001). Hence, areas with higher vent fluid emissions favour the recruitment of vent fauna (Metaxas and Kelly, 2010). However, the patterns were different for the Plum et al. 2016 study, in which trends in copepods density were linked to the substratum type. That is, an increasing density with decreasing fluid emission was reported from wood substrata; on bone and slate substrata copepod density tended to decrease from high and intermediate vent activity sites to the external ones. A higher taxonomic richness was reported on the sponges located at the most active sites. The dominance of certain groups, such as bivalve settlers on E4 or ostracods on E5 has an impact on the rarefaction diversity indices, so that the highest diversities are found on the site with no hydrothermal influence for the total fauna and macrofauna and at site 4 for the meiofauna. The colonization index was also higher on the substrata from the active sites than on those from the less active to inactive sites, suggesting that the presence of fluids is favourable to recruitment.

Variations in vent fluid composition is one of the main driver of faunal composition at Eiffel Tower (Cuvelier et al. 2011b, Sarrazin et al. 2015, Husson et al. 2016). This is in accordance with several 
vent ecological studies showing that thermal conditions (and associated factors) play a key role in defining spatial distribution of the hydrothermal fauna. Similarly, we found that the variability in faunal composition could be explained mainly by the position of our sponges from fluid emission. This was confirmed by the PCA analysis that support a significant difference in community composition (abundance, diversity, composition) between the sponges from the active $(2 \& 3)$ and inactive ( $4 \& 5)$ sites. Gradients of temperature and hydrothermal flux also influenced faunal abundance and diversity in other vent colonization experiments (Shank et al. 1998; Mullineaux et al. 2010; Kelly et al. 2007). In addition to the environment, the distribution, abundance and diversity of settlers are also determined by other factors, including biological interactions (Mullineaux et al. 2003; Bates et al. 2005).

\subsection{Influence of substratum heterogeneity: some preliminary considerations}

The presence of complex physical structures at hydrothermal vents may lead to the formation of microhabitats (Kelly and Metaxas 2008). This increased heterogeneity may contribute to the provision of space and accumulation of food sources and offer protection against predators (Van Dover 2003; Govenar and Fisher 2007; Kelly and Metaxas 2008). Therefore, substratum heterogeneity is expected to positively influence diversity, richness and abundance of associated fauna (Govenar et al. 2005; Bergquist et al. 2007).

This study shows that the complex structure of synthetic sponges supports colonization by the vent fauna. Studies with inorganic sponges as colonizing substrata were previously performed on the East Pacific Rise (Kelly and Metaxas 2008; Gollner et al. 2013, 2015). These studies showed that artificial sponges were a suitable colonization substratum as they significantly contribute to enhance the abundance (higher abundance compared to basalts), diversity (higher number of taxa on sponges) and evenness of colonizers compared to other inorganic substrata (e.g. basalt). 
Kelly and Metaxas (2008) reported that the complex structure of sponges contributed to the successful colonization of smaller species of polychaetes, larvae of gastropods and meiofaunal taxa. Similarly, the sponges deployed at Eiffel Tower (present study) harboured a high percentage of juveniles and larval stages (e.g. larvae of gastropods). A sex ratio biased in favour of nematode females was found in our sponge samples and high percentages of gravid nematode females of Cephalochaetosoma (27\%-50\%) and Halomonhystera (65\%-84\%) were observed at the high and intermediate vent sites, indicating a mature community in reproductive stage. The presence of abundant nauplii and juvenile copepod stages on sponges from active sites supported previous observations from other inorganic and organic substrata (Plum et al. 2016) and from natural community (Ivanenko et al. 2012, Sarrazin et al. 2015). This finding indicates that the Eiffel Tower copepod community is well established and is able to thrive in different microhabitats (Sarrazin et al. 2015, Plum et al. 2016) and also contradict previous assumptions that copepod larval stages would only inhabit micro-habitats outside the hydrothermal influence (Tsurumi et al. 2001).

Although better replication and an in depth taxonomic identification are needed, results from our pilot study suggest that synthetic sponges can be a suitable colonizing substratum for some taxa not found on other organic and inorganic substrata (e.g. ophiuroids, pycnogonids, cnidarians and foraminiferans). Moreover, sponges can act as a trap for juveniles and larvae of benthic fauna likely due to their 3-dimensional/convolute shape and their position at $\sim 50 \mathrm{~cm}$ above the bottom which may have contributed to the retention of swimming larvae. Substratum properties (e.g. roughness, heterogeneity, presence of small interstitial spaces) rather that their nature (e.g. organic vs inorganic) may be more important in favoring larval settlement (Balazy and Kuklinski 2017). As they favor settlers from the water column compared to benthic immigrants (regardless of their life stage), sponge substratum floating above the seafloor may provide valuable insights in terms of export of colonists from the benthic community to the bentho-pelagic compartment and import of planktonic colonists to the benthic communities. This might significantly improve our understanding of mechanisms and sources of recolonization in challenged benthic habitats. 


\section{Acknowledgements}

Special thanks to the captains and crews of the R/V Pourquoi Pas? and the pilots of the Victor6000 ROV for their great support during the MoMARSAT and BIOBAZ cruises. We are also very grateful to the LEP technical and engineering teams for their support at sea and in the laboratory. This work was supported by the "Laboratoire d'Excellence" LabexMER (ANR-10-LABX-19) and EGIDE Campus France, is co-funded by a grant from the French government under the program "Investissements d'Avenir" and is part of the EMSO-Acores research program funded by an ANR research grant (ANR Lucky Scales ANR-14-CE02-0008-02). DZ was partially supported the by the project "Prokaryote-nematode Interaction in marine extreme envirONments: a uniquE source for ExploRation of innovative biomedical applications" (PIONEER) funded by the Total Foundation and Ifremer.

Conflict of Interest: The authors declare that they have no conflict of interest.

Ethical approval: This article does not contain any studies with animals performed by any of the authors.

Field study: Permits and approval of field or observational studies have been obtained by the authors, if applicable.

\section{References}

Anderson MJ, Gorley, RN, Clarke KR (2008) PERMANOVA+ for PRIMER: guide to software and statistical methods. PRIMER-E, Plymouth

Baker MC, Ramirez-Llodra EZ, Tyler PA, German CR, Boetius A, Cordes EE, Dubilier N, Fisher 
CR, Levin LA, Metaxas A, Rowden AA, Santos RS, Shank TM, Van Dover CL, Young CM, Warén A (2010) Biogeography, ecology, and vulnerability of chemosynthetic ecosystems in the deep sea, in: McIntyre, A.D., (Eds.), Life in the World's Oceans. Blackwell Publishing Ltd., pp $161-183$

Balazy P, Kuklinski P (2017) Arctic field experiment shows differences in epifaunal assemblages between natural and artificial substrates of different heterogeneity and origin. J Exp Mar Biol Ecol 486: 178-187

Bates AE, Tunnicliffe V, Lee RW (2005) Role of thermal conditions in habitat selection by hydrothermal vent gastropods. Mar Ecol Prog Ser 305: 1-15

Beaulieu SE, Baker ET, German CR, Maffei A (2013) An authoritative global database for active submarine hydrothermal vent fields. Geochem Geophys Geosys 14: 4892-4905

Beaulieu SE, Baker ET, German CR (2015) Where are the undiscovered hydrothermal vents on oceanic spreading ridges? Deep Sea Res II: Topical Stud Oceanogr 121: 202-212

Bergquist DC, Eckner JT, Urcuyo IA, Cordes EE, Hourdez S, Macko SA, Fisher CR (2007) Using stable isotopes and quantitative community characteristics to determine a local hydrothermal vent food web. Mar Ecol Prog Ser 330: 49-65

Bertness MD, Leonard GH, Levine JM, Schmidt PR, Ingraham AO (1999) Testing the relative contribution of positive and negative interactions in rocky intertidal communities. Ecology 80: 2711-2726

Boeckner MJ, Sharma J, Proctor HC (2009) Revisiting the meiofauna paradox: dispersal and colonization of nematodes and other meiofaunal organisms in low- and high-energy environments. Hydrobiologia 624: 91-106

Charlou JL, Donval JP, Douville E, Jean-Baptiste P, Radford-Knoery J, Fouquet Y, Dapoigny A, Stievenard M (2000) Compared geochemical signatures and the evolution of Menez Gwen 
$\left(37^{\circ} 500 \mathrm{~N}\right)$ and Lucky Strike $\left(37^{\circ} 170 \mathrm{~N}\right)$ hydrothermal fluids, south of the Azores Triple Junction on the Mid-Atlantic Ridge. Chem Geol 171: 49-75

Clarke KR (1993) Non-parametric multivariate analyses of changes in community structure. Aust J Ecol 18: 117-143

Comtet T, Desbruyères D (1998) Population structure and recruitment in mytilid bivalves from the Lucky Strike and Menez Gwen hydrothermal vent fields $\left(37^{\circ} 17^{\prime} \mathrm{N}\right.$ and $37^{\circ} 50^{\prime} \mathrm{N}$ on the MidAtlantic Ridge). Mar Ecol Prog Ser 63: 165-177

Copley JTP, Flint HC, Ferrero TJ, Van Dover CL (2007) Diversity of meiofauna and free-living nematodes in mussel beds at hydrothermal vents on the northern and southern East Pacific Rise. J Mar Biol Assoc UK84: 1141-1152.

Cuvelier D, Sarrazin J, Colaço A, Copley J., Desbruyères D, Glover AG, Tyler P, Santos R (2009)

Distribution and spatial variation of hydrothermal faunal assemblages at Lucky Strike (Mid-Atlantic Ridge) revealed by high-resolution video image analysis. Deep Sea Res Part I: Oceanogr Res Pap 56: $2026-2040$

Cuvelier D, Sarradin PM, Sarrazin J, Colaço A, Copley JT, Desbruyères D, Glover AG, Serrão Santos R, Tyler PA (2011a) Hydrothermal faunal assemblages and habitat characterization at the Eiffel tower edifice (Lucky Strike, mid-Atlantic Ridge). Mar Ecol Evol Perspect 32: 243-255

Cuvelier D, Sarrazin J, Colaço A, Copley JT, Glover AG, Tyler PA, Serrão Santos R, Desbruyères D (2011b) Community dynamics over 14 years at the Eiffel Tower hydrothermal edifice on the Mid-Atlantic Ridge. Limnol Oceanogr 56: 1624-1640

Cuvelier D, Beesau J, Ivanenko VN, Zeppilli D, Sarradin PM, Sarrazin J (2014). Colonisation and diversity patterns on organic and inorganic substrata and the influence of hydrothermal activity at Atlantic deep-sea vents. Deep Sea Res Part I 87: 70-81 
De Busserolles F, Sarrazin J, Gauthier O, Gélinas Y, Fabri MC, Sarradin PM, Desbruyères D (2009) Are spatial variations in the diets of hydrothermal fauna linked to local environmental conditions? Deep Sea Res Part II: Top Stud Oceanogr 56: 1649-1664

Deprez T, Steyaert M, Vanaverbeke J, Speybroeck J, Raes M, Derycke S, De Smet G, Ingels J, Vanreusel A, Van Gaever S, Vincx M, (2005) NeMys. World Wide Web Electronic Publication (www.nemys.ugent.be). Department of Marine Biology, Ghent University

Eckman JE (1987) The role of hydrodynamics in recruitment, growth, and survival of Agropecten irradians (L.) and Anomia simplex (D’orbigny) within eelgrass meadows. J Exp Mar Biol Ecol 106: $165-191$

Fabri MC, Bargain A, Briand P, Gebruk A, Fouquet Y, Morineaux M, Desbruyères D (2011) The hydrothermal vent community of a new deep-sea field, Ashadze- $1,12^{\circ} 58^{\prime} \mathrm{N}$ on the Mid-Atlantic Ridge. J Mar Biol Ass UK 91 : 1-13

Fonseca-Genevois V, Somerfield PJ, Neves MHB, Coutinho R, Moens T (2006) Colonization and early succession on artificial hard substrata by meiofauna. Mar Biol 148: 1039-1050

Gaudron SM, Pradillon F, Pailleret M, Duperron S, Le Bris N, Gaill F (2010) Colonization of organic substrates deployed in deep-sea reducing habitats by symbiotic species and associated fauna. Mar Environ Res 70: 1-12

Gauthier O, Sarrazin J, Desbruyères D (2010) Measure and mis-measure of species diversity in deep-sea chemosynthetic communities. Mar Ecol Prog Ser 402: 285-302

Giere O (2009) Meiobenthology, the microscopic mobile fauna of aquatic sediments. Springer Verlag, Berlin

Gollner S, Zekely J, Govenar B, LeBris N, Nemeschkal HL, Fisher CR, Bright M (2007) Tubeworm-associated permanent meiobenthic communities from two chemically different hydrothermal vent sites on the East Pacific Rise. Mar Ecol Prog Ser 337: 39-49 
617 Gollner S, Riemer B, Martinez Arbizu P, Le Bris N, Bright M (2010) Diversity of meiofauna from 1 618 the $9^{\circ} 50^{\prime} \mathrm{N}$ East Pacific rise across a gradient of hydrothermal fluid emissions. PLoS ONE 5(8): $\stackrel{4}{619} \quad \mathrm{e} 12321$

Gollner S, Miljutina M, Bright M (2013) Nematode succession at deep-sea hydrothermal vents after a recent volcanic eruption with the description of two dominant species. Org Divers Evol 13: 349371

Gollner S, Govenar B, Martinez Arbizu P, Mills S, Le Bris N, Weinbauer M, Shank TM, Bright M, (2015) Differences in recovery between deep-sea hydrothermal vent and vent-proximate communities after a volcanic eruption. Deep Sea Res I 106: 167-182

Govenar B, Le Bris N, Gollner S, Glanville J, Aperghis AB, Hourdez S, Fisher CR (2005) Epifaunal community structure associated with Riftia pachyptila aggregations in chemically different hydrothermal vent habitats. Mar Ecol Prog Ser 305: 67-77

Govenar B, Fisher CR (2007) Experimental evidence of habitat provision by aggregations of Riftia pachyptila at hydrothermal vents on the East Pacific Rise. Mar Ecol Evol Perspect 2: 3-14

Higgins RP, Thiel H (1988) Introduction to the study of meiofauna. D.C. Smithsonian Institution Press, Washington p.488

Hull SL (1997) Seasonal changes in diversity and abundance of ostracods on four species of intertidal algae with differing structural complexity. Mar Ecol Prog Ser 161: 71-82

Humphris SE, Fornari DJ, Scheirer DS, German CR, Parson LM (2002) Geotectonic setting of hydrothermal activity on the summit of Lucky Strike seamount (37 Degrees $17^{\prime} \mathrm{N}$, Mid-Atlantic Ridge). Geochem Geophys Geosyst. doi:10.1029/2001GC000284

Husson B, Sarradin PM, Zeppilli D, Sarrazin J (2017) Picturing thermal niches and biomass of hydrothermal vent species. Deep-sea Res Part II 137: 6-25 
Ivanenko VN, Ferrari FD, Defaye D, Sarradin PM, Sarrazin J (2011) Description, distribution and microhabitats of a new species of Tisbe (Copepoda: Harpacticoida: Tisbidae) from a deep-sea hydrothermal vent field at the Mid-Atlantic Ridge (37N, Lucky Strike). Cah Biol Mar 523: 61-361 Ivanenko VN, Corgosinho PH, Ferrari F, Sarradin PM, Sarrazin J (2012) Microhabitat distribution of Smacigastes micheli (Copepoda: Harpacticoida: Tegastidae) from deep - sea hydrothermal vents at the Mid - Atlantic Ridge, $37^{\circ} \mathrm{N}$ (Lucky Strike), with a morphological description of its nauplius. Mar Ecol 33: 246-256

Kelly NE, Metaxas A, Butterfield DA (2007) Spatial and temporal patterns of colonization by deepsea hydrothermal vent invertebrates on the Juan de Fuca Ridge, NE Pacific. Aquat Biol 1: 1

Kelly N, Metaxas A (2008) Diversity of invertebrate colonists on simple and complex substrates at hydrothermal vents on the Juan de Fuca Ridge. Aquat Biol 3: 271-281

Lutz RA, Shank TM, Luther GW, Vetriani C, Tolstoy M, Nuzzio DB, Moore TS, Waldhauser F, Crespo-Medina M, Chatziefthimiou AD, Annis ER, Reed AJ (2008) Interrelationships between vent fluid chemistry, temperature, seismic activity, and biological community structure at a musseldominated, deep-sea hydrothermal vent along the East Pacific Rise. J Shellfish Res 27: 177-190

Marcus J, Tunnicliffe V, Butterfield D (2009) Post-eruption succession of macrofaunal communities at diffuse flow hydrothermal vents on Axial Volcano, Juan de Fuca Ridge, Northeast Pacific. Deep Sea Res Part II 56: 1586-1598

McArdle BH, Anderson MJ (2001) Fitting multivariate models to community data: a comment on distance-based redundancy analysis. Ecology 82: 290-297

Maolic Y, Desbruyères D, Duarte CM, Rozenfeld AF, Bachraty C, Arnaud-Haond S (2012) Biogeography revisited with network theory: retracting the history of hydrothermal veb communities. Syst Biol 61: 127-137 

20

Metaxas A, Kelly NE (2010) Do Larval supply and recruitment vary among chemosynthetic environments of the deep sea? PLoS ONE 5 (7): e11646

Mullineaux LS, Peterson CH, Micheli F, Mills SW (2003) Successional mechanism varies along a gradient in hydrothermal fluid flux at deep-sea vents. Ecol Monogr 73: 523-542

Mullineaux LS, Adams DK, Mills SW, Beaulieu SE (2010) Larvae from afar colonize deep-sea hydrothermal vents after a catastrophic eruption. PNAS 107: 7829-7834

Ondréas H, Cannat M, Fouquet Y, Normand A, Sarradin PM, Sarrazin J (2009) Recent volcanic events and the distribution of hydrothermal venting at the Lucky Strike hydrothermal field, MidAtlantic Ridge. Geochem Geophys Geosyst 10(2):1-18

Palmer MA (1988) Dispersal of marine meiofauna: a review and conceptual model explaining passive transport and active emergence with implications for recruitment. Mar Ecol Prog Ser 48: $81-91$

Platt HM, Warwick RM (1983) A synopsis of the freeliving marine nematodes. Part I: British Enoplids. Cambridge University Press, Cambridge

Platt HM, Warwick RM (1988) A synopsis of the freeliving marine nematodes. Part II: British Chromadorids. Cambridge University Press, Cambridge

Plum C, Pradillon F, Fujivara Y, Sarrazin J (2016) Copepod colonization of organic and inorganic substrata at a deep-sea hydrothermal vent site on the Mid-Atlantic Ridge. Deep Sea Res II doi: 10.1016/j.dsr2.2016.06.008i

Romey WL, Castro KM, Dealteris JT, Bullock RC (1991) Recruitement in the deep-sea woodboring bivalve Xylophaga atlantica Richards. The Veliger 34: 14-20 
Sarradin PM, Waeles M, Bernagout S, Le Gall C, Sarrazin J, Riso R (2009) Speciation of dissolved copper within an active hydrothermal edifice on the Lucky Strike vent field (MAR, 37N). Sci Total Environ $407: 869-878$

Sarrazin J, Cuvelier D, Peton L, Legendre P, Sarradin PM (2014) High-resolution dynamics of a deep-sea Hydrothermal mussel assemblage monitored by the EMSO-Açores MoMAR observatory. Deep-sea Res I: Oceanogr Res Papers 90: 62-75

Sarrazin J, Legendre P, DeBusserolles F, Fabri M-C, Guilini K, Ivanenko VN, Morineaux M, Vanreusel A, Sarradin P-M (2015) Biodiversity patterns, environmental drivers and indicator species on a high-temperature hydrothermal edifice, mid-Atlantic ridge. Deep Sea Res. Part II: Top Stud Oceanogr 121:177-192

Schander C, Rapp HT, Kongsrud JA, Bakken T, Bergen J, Cochrane S, Oug E, Byrkjedal I, Todt C, Cedhagen T, Fosshagen A, Gebruk A, Larsen K, Levin L, Obst M, Pleijel F, Stöhr S, Warén A, Mikkelsen NT, Hadler-Jacobsen S, Keuning R, Petersen KH, Thorseth IH, Peddersen RB (2010)

The fauna of hydrothermal vents on the Mohan Ridge (North Atlantic). Mar Biol Res 6: 155-171

Shank TM, Fornari DJ, Von Damm KL, Lilley MD, Haymon RM, Lutz RA (1998) Temporal and spatial patterns of biological community development at nascent deep-sea hydrothermal vents (9 degrees 50' N, East Pacific Rise). Deep- Sea Res Part II 45(1-3): 465

Sibert JR (1981) Intertidal hyperbenthic populations in the Nanaimo Estuary. Mar Biol 64: 259-265

Soltwedel T (2000) Metazoan meiobenthos along continental margins: a review. Prog Oceanogr 46: 59-84

Tolstoy M, Cowen JP, Baker ET, Fornari DJ, Rubin KH, Shank TM, Waldhauser F, Bohnenstiehl DR, Forsyth DW, Holmes RC, Love B, Perfit MR, Weekly RT, Soule SA, Glazer B (2006) A seafloor spreading event captured by seismometers. Science 314: 1920-1922 
Tsurumi M, Tunnicliffe V (2001) Characteristics of a hydrothermal vent assemblage on a volcanically active segment of Juan de Fuca Ridge, northeast Pacific. Can J Fish Aquat Sci 58: 530-542

Tsurumi M (2003) Diversity at hydrothermal vents. Global Ecol Biogeogr 12: 181-190

Tsurumi M, Tunnicliffe V (2003) Tubeworm-associated communities at hydrothermal vents on

the Juande Fuca Ridge, northeast Pacific. Deep- Sea Res Part I 50: 611-629

Tunnicliffe V (1991) The biology of hydrothermal vents - Ecology and evolution. Oceanogr Mar Biol 29: 319-407

Tunnicliffe V, Embley RW, Holden JF, Butterfield DA, Massoth GJ, Juniper SK (1997) Biological colonization of new hydrothermal vents following an eruption on Juan de Fuca Ridge. Deep-Sea Res I 44: 1627-1644

Van Dover CL, Desbruyères D, Segonzac M, Comtet T, Saldanha L, Fiala- Medioni A, Langmuir C (1996) Biology of the Lucky Strike hydrothermal field. Deep Sea Res Part I: Oceanogr Res Pap 43:1509-1529

Van Dover CL (2002) Community structure of mussel beds at deep-sea hydrothermal vents. Mar Ecol Prog Ser 230: 137-158

Van Dover CL (2003) Variation in community structure within hydrothermal vent mussel beds of the East Pacific Rise. Mar Ecol Prog Ser 253: 55-66

Vanreusel A, VandenBossche I, Thiermann F (1997) Free-living marine nematodes from hydrothermal sediments: similarities with communities from diverse reduced habitats. Mar Ecol Prog Ser 157: 207-219 

20

Vanreusel A, De Groote A, Gollner S, Bright M (2010) Ecology and biogeography of free-living nematodes associated with chemosynthetic environments in the deep sea: a review. Plos One 5 (8): 15

Warwick RM (1984) Species size distributions in marine benthic communities. Oecologia 61: 32-41

Warwick RM, Howard HM, Somerfield PJ (1998) A synopsis of the freeliving marine nematodes.

Part III: Monhysterids. Field Studies Council, Shrewsbury.

Zekeley J, Van Dover CL, Nemeschkal HL, Bright M (2006) Hydrothermal vent meiobenthos associated with mytilid mussel aggregations from the Mid-Atlantic Ridge and the East Pacific Rise.

Deep Sea Res Part I 53: 1363-1378

Zeppilli D, Vanreusel A, Pradillon F, Fuchs S, Mandon P, James T, Sarrazin J (2015) Rapid colonization by nematodes on organic and inorganic substrata deployed at the deep-sea Lucky Strike hydrothermal vent field (Mid-Atlantic Ridge). Mar Biodiv. doi 10.1007/s12526-015-0348-2 
49

\section{Tables}

Table 1 Location, depth and temperature of the sites where the substrata were deployed in the vicinity of the Eiffel Tower edifice (Lucky Strike vent field, MAR). Sponge E1 was lost during recovery. $\mathrm{T}^{\circ} \mathrm{C}$ was measured with autonomous temperature probes deployed at each site. Standard deviations are given in parenthesis. Fluid inputs (\%) have been estimated using the formula provided by Sarradin et al. (2009).

\begin{tabular}{ccccc}
\hline Substratum & E2 & E3 & E4 & E5 \\
\hline Emission & High & Intermediate & Inactive & External \\
Latitude (N) & $37^{\circ} 17.3484^{\prime}$ & $37^{\circ} 17.3404^{\prime}$ & $37^{\circ} 17.3181^{\prime}$ & $37^{\circ} 17.465^{\prime}$ \\
Longitude (W) & $32^{\circ} 16.5333^{\prime}$ & $32^{\circ} 16.5379^{\prime}$ & $32^{\circ} 16.5331^{\prime}$ & $32^{\circ} 16.800^{\prime}$ \\
Depth (m) & 1699 & 1698 & 1705 & 1741 \\
$\mathrm{~T}^{\circ} \mathrm{C}$ & $7.3( \pm 1.56)$ & $5.5( \pm 0.55)$ & $4.7( \pm 0.13)$ & $4.3( \pm 0.07)$ \\
$\%$ Fluid & 0.91 & 0.35 & 0.096 & 0.05 \\
\hline
\end{tabular}

Table 2 Meiofaunal, macrofaunal and total faunal abundances on the sponge substrata recovered after 24 months. The colonization rate index $(\mathrm{CI})$ is also reported and calculated by dividing the number of animals $\left(\right.$ per $\left.\mathrm{m}^{2}\right)$ by the number of days the substrata stayed at the seafloor.

\begin{tabular}{|c|c|c|c|c|c|c|}
\hline Site code & $\begin{array}{c}\text { Meiofauna } \\
\text { (ind./m²) }\end{array}$ & $\begin{array}{c}\text { Macrofauna } \\
\text { (ind./m²) }\end{array}$ & $\begin{array}{c}\text { Total fauna } \\
\text { (ind./m²) }\end{array}$ & $\begin{array}{l}\text { Meiofauna CI } \\
\text { (ind./m²/day) }\end{array}$ & $\begin{array}{c}\text { Macrofauna CI } \\
\text { (ind./m²/day) }\end{array}$ & $\begin{array}{c}\text { Total fauna CI } \\
\text { (ind./m²/day) }\end{array}$ \\
\hline $\mathrm{E} 2$ & 166736 & 9081 & 175818 & 218.2 & 11.9 & 230.7 \\
\hline E3 & 84622 & 4226 & 88846 & 110.8 & 5.5 & 116.3 \\
\hline E4 & 371 & 160 & 532 & 0.5 & 0.2 & 0.7 \\
\hline E5 & 255 & 473 & 727 & 0.3 & 0.6 & 0.95 \\
\hline
\end{tabular}


Table 3 Taxonomic composition and densities of meiofaunal and macrofaunal organisms colonizing the inorganic sponges deployed at the Eiffel Tower edifice (Lucky Strike vent field, MAR) after a two-year experiment. Higher values are indicated in bold. In the group of 'others' are included: molluscs and miscellaneous specimens too damaged to be identified.

\begin{tabular}{|c|c|c|c|c|c|}
\hline \multirow[t]{2}{*}{ Taxon } & \multirow[t]{2}{*}{ Species } & \multicolumn{4}{|c|}{ Densities (ind./m2) } \\
\hline & & E2 & E3 & E4 & E5 \\
\hline \multicolumn{6}{|l|}{ Annelida } \\
\hline \multicolumn{6}{|l|}{$\overline{\text { Polychaeta }}$} \\
\hline \multirow[t]{2}{*}{ Glyceridae } & Glyceridae sp1 & 2.2 & 0.0 & 0.0 & 0.0 \\
\hline & Glyceridae sp2 & 0.0 & 0.0 & 0.0 & 6.6 \\
\hline Ampharetidae & Undetermined sp. & 679.1 & 347.3 & 0.0 & 0.0 \\
\hline \multirow[t]{2}{*}{ Dorvilleidae } & Undetermined sp. & 1907.7 & 301.1 & 0.0 & 0.0 \\
\hline & Ophryotrocha sp. & 0.0 & 0.0 & 0.0 & 74.7 \\
\hline \multirow[t]{2}{*}{ Polynoidae } & Branchipolynoe cf. seepensis & 19.8 & 17.6 & 0.0 & 0.0 \\
\hline & Undetermined sp. & 2.2 & 0.0 & 0.0 & 0.0 \\
\hline Spionidae & Laonice sp. & 2.2 & 6.6 & 0.0 & 0.0 \\
\hline \multirow{3}{*}{ Hesionidae } & Hesionidae sp1 & 35.2 & 0.0 & 0.0 & 0.0 \\
\hline & Hesionidae sp2 & 0.0 & 0.0 & 0.0 & 44.0 \\
\hline & Hesionidae sp3 & 0.0 & 0.0 & 0.0 & 30.8 \\
\hline Trichobranchidae & Undetermined sp. & 0.0 & 0.0 & 0.0 & 4.4 \\
\hline Polychaete larvae & Undetermined sp. & 709.9 & 167.0 & 0.0 & 52.7 \\
\hline \multicolumn{6}{|l|}{ Arthropoda } \\
\hline \multicolumn{6}{|l|}{$\overline{\text { Crustacea }}$} \\
\hline \multicolumn{6}{|l|}{ Maxillopoda } \\
\hline Copepoda & Undetermined sp. & 21863.7 & 23356.0 & 162.6 & 191.2 \\
\hline Nauplii & Undetermined sp & 27013.2 & 29580.2 & 0.0 & 0.0 \\
\hline Ostracoda & Undetermined sp. & 740.7 & 120.9 & 134.1 & 208.8 \\
\hline \multicolumn{6}{|l|}{ Malacostraca } \\
\hline Amphipoda & Undetermined sp. & 0.0 & 2.2 & 0.0 & 33.0 \\
\hline \multicolumn{6}{|l|}{ Chelicerata } \\
\hline \multicolumn{6}{|l|}{ Arachnida } \\
\hline Halacaridae & Undetermined sp. & 241.8 & 76.9 & 0.0 & 0.0 \\
\hline Pycnogonida & Undetermined sp. & 0.0 & 2.2 & 0.0 & 0.0 \\
\hline Hexapoda & Undetermined sp. & 4.4 & 0.0 & 0.0 & 0.0 \\
\hline \multicolumn{6}{|l|}{ Echinodermata } \\
\hline Ophiuroidea & Undetermined sp. & 2.2 & 2.2 & 0.0 & 0.0 \\
\hline Foraminifera & Undetermined sp. & 83.5 & 24.2 & 33.0 & 0.0 \\
\hline \multicolumn{6}{|l|}{$\overline{\text { Mollusca }}$} \\
\hline Mytilidae & Bathymodiolus azoricus & 241.8 & 692.3 & 0.0 & 0.0 \\
\hline Bivalve settlers & Undetermined sp. & 0.0 & 2.2 & 180.2 & 74.7 \\
\hline \multicolumn{6}{|l|}{ Gastropoda } \\
\hline \multirow{3}{*}{ Lepetodrilidae } & Lepetodrilus sp. & 0.0 & 0.0 & 0.0 & 6.6 \\
\hline & Lepetodrilus atlanticus & 33.0 & 149.5 & 0.0 & 0.0 \\
\hline & Pseudorimula midatlantica & 4.4 & 0.0 & 0.0 & 0.0 \\
\hline
\end{tabular}




\section{Orbitestellidae \\ Skeneidae}

\section{Nematoda}

Draconematidae

Monhysteridae

Oncholaimidae

Cnidaria

Others

Total density

$\begin{array}{cccc}30.8 & 22.0 & 0.0 & 0.0 \\ 112.1 & 661.5 & 17.6 & 0.0 \\ 0.0 & 0.0 & 4.4 & 0.0 \\ \mathbf{1 0 6} \mathbf{9 7 7 . 2} & 28299.0 & 0.0 & 0.0 \\ 14313.7 & 5008.7 & 0.0 & 0.0 \\ 715.7 & 0.0 & 0.0 & 0.0 \\ 2.2 & 0.0 & 0.0 & 0.0 \\ 79.1 & 6.6 & 0.0 & 0.0\end{array}$

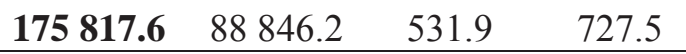

Table 4 Distribution of the different taxa on the sponges substrata at active (E2), intermediate (E3), inactive

(E4) and external (E5) sites. Only a few taxa are shared between active (E2 and E3) and inactive sites (E4 and E5). Ma: organisms found exclusively in the macrofaunal size class ( $>250 \mu \mathrm{m})$, Me: organisms found exclusively to the meiofaunal size class (between $20 \mu \mathrm{m}$ and $250 \mu \mathrm{m}$ ), Me/Ma: organisms found in both meiofaunal and macrofaunal size classes.

\begin{tabular}{lcc}
\multicolumn{1}{c}{ Organism } & E2 & E3 \\
\hline Polychaetes & & \\
Glyceridae sp 1 & $\mathrm{Ma}$ & \\
Glyceridae sp2 & $\mathrm{Me} / \mathrm{Ma}$ & $\mathrm{Me} / \mathrm{Ma}$ \\
Ampharetidae & $\mathrm{Me} / \mathrm{Ma}$ & $\mathrm{Me} / \mathrm{Ma}$ \\
$\begin{array}{l}\text { Dorvilleidae undet } \\
\text { Dorvilleidae : Ophryotrocha sp }\end{array}$ & $\mathrm{Ma}$ & \\
$\begin{array}{l}\text { Polynoidae undet } \\
\text { Polynoidae : Branchipolynoe }\end{array}$ & & \\
$\begin{array}{l}\text { seepensis } \\
\text { Spionidae : Laonice sp. }\end{array}$ & $\mathrm{Ma}$ & $\mathrm{Ma}$ \\
Hesionidae sp. 1 & $\mathrm{Ma}$ & $\mathrm{Ma}$ \\
Hesionia & $\mathrm{Me}$ &
\end{tabular}

Hesionidae sp 2

Hesionidae sp 3

$\mathrm{Ma}$

Trichobranchidae undet

$\mathrm{Ma}$

Polychaete larvae

$\mathrm{Me} / \mathrm{Ma} \quad \mathrm{Me} / \mathrm{Ma}$

$\mathrm{Ma}$

\section{Crustacea}

Copepoda undet

$\mathrm{Me} / \mathrm{Ma} \quad \mathrm{Me} / \mathrm{Ma} \quad \mathrm{Me} / \mathrm{Ma} \quad \mathrm{Me} / \mathrm{Ma}$

Copepoda nauplii

$\mathrm{Me} / \mathrm{Ma} \quad \mathrm{Me} / \mathrm{Ma}$

Ostracoda undet

$\mathrm{Me} / \mathrm{Ma} \quad \mathrm{Me} / \mathrm{Ma} \quad \mathrm{Me} / \mathrm{Ma} \quad \mathrm{Me} / \mathrm{Ma}$

Amphipoda undet $\mathrm{Ma}$ $\mathrm{Ma}$

\section{Chelicerata}

Halacaridae undet 
Pycnogonida undet

Ma

Hexapoda undet

$\mathrm{Ma}$

Echinodermata

Ophiuroidea undet Ma

$\mathrm{Ma}$

\section{Foraminifera}

Foraminifera undet

$\mathrm{Me} / \mathrm{Ma} \quad \mathrm{Me} / \mathrm{Ma} \quad \mathrm{Me} / \mathrm{Ma}$

\section{Mollusca}

Mytilidae : Bathymodiolus azoricus

Bivalve settlers

Lepetodrilus sp.

Lepetodrilus atlanticus

Pseudorimula midatlantica

Lurifax vitreus

Ma $\quad$ Ma

Protolira sp.

$\mathrm{Me} / \mathrm{Ma} \quad \mathrm{Me} / \mathrm{Ma} \quad \mathrm{Me} / \mathrm{Ma}$

\section{Nematoda}

Nematoda undet.

Cephalochaetosoma

Halomonhystera

Oncholaimus

\section{Cnidaria}

Cnidaria undet

$\mathrm{Ma}$

others'

$\mathrm{Me} / \mathrm{Ma} \quad \mathrm{Me} / \mathrm{Ma}$

Table 5 Meiofaunal, macrofaunal and total faunal diversity colonizing the inorganic sponges at the Eiffel Tower. Taxonomic richness (TR, no larvae and nauplii) and the rarefaction biodiversity indices ( $n=50$ and $n=100)$ are reported. Higher values are indicated in bold.

\begin{tabular}{clccc} 
& Substratum & TR & ES(50) & ES(100) \\
\hline Meiofauna & E2 & $\mathbf{1 3}$ & 3.1 & 3.9 \\
& E3 & 10 & 2.9 & 3.7 \\
& E4 & 5 & $\mathbf{4 . 4}$ & $\mathbf{4 . 8}$ \\
& E5 & 2 & 2.0 & 2.0 \\
\hline Macrofauna & E2 & $\mathbf{1 9}$ & 5.5 & 7.1 \\
& E3 & 16 & 6.0 & 7.4 \\
& E4 & 2 & 2.0 & - \\
& E5 & 9 & $\mathbf{7 . 8}$ & $\mathbf{8 . 6}$ \\
\hline Total fauna & E2 & $\mathbf{2 5}$ & 5.4 & 6.5 \\
& E3 & 21 & 5.2 & 6.3 \\
& E4 & 6 & 5.1 & 5.5 \\
& E5 & 11 & $\mathbf{8 . 8}$ & $\mathbf{9 . 7}$ \\
\hline
\end{tabular}


Table 6 Results of the DistLM analysis (Selection criterion: R²; Selection procedure: step-wise) highlighting 4 789 the effect of environmental variables on faunal abundance and diversity on inorganic sponges at the Eiffel 6 790 Tower edifice (Emission: position from fluid emission; SS: sum of squares; F: F statistic; P: probability 8 791 level; $* \mathrm{P}<0.05$; ns: not significant).

\begin{tabular}{llccccc} 
& Variables & SS & F & P & & $\begin{array}{c}\text { Variance } \\
(\%)\end{array}$ \\
\hline Faunal taxa composition & Emission & 5825.5 & 3.645 & $\mathbf{0 . 0 4 2}$ & $*$ & $\mathbf{6 6}$ \\
& Fluid (\%) & 881.48 & 0.381 & 0.840 & ns & 8 \\
Faunal abundance & Emission & 5331.9 & 4.704 & 0.175 & ns & 70 \\
& Fluid (\%) & 370.59 & 0.195 & 0.904 & ns & 5 \\
Rarefaction indices & Emission & 55.821 & 2.081 & 0.311 & ns & 51 \\
$(n=50 ; n=100)$ & Fluid (\%) & 40.481 & 3.074 & 0.379 & ns & 37 \\
\hline
\end{tabular}




\section{Figure captions}

Fig. 1 Location of the Lucky Strike vent field on the Mid Atlantic Ridge (MAR). Pictures showing the sampling sites at the Eiffel Tower where the inorganic sponges have been deployed in 2011. Site 2: high hydrothermal fluid emission; Site 3: intermediate hydrothermal fluid emission; Site 4: inactive site; Site 5: external site

Fig. 2 Meio- and macrofaunal density (ind. $/ \mathrm{m}^{2}$ ) reported from the synthetic sponges deployed at the Eiffel Tower edifice.

Fig. 3 (a) Faunal community structure characterizing the inorganic sponges deployed in the vicinity of Eiffel Tower. The contribution of the major taxa is expressed as \%; the group 'others' include all taxa representing less than $1 \%$ (i.e. cnidarians, echinoderms, foraminifers, chelicerates, hexapods); (b) percentage of juveniles/larvae found (i.e. polychaetes, bivalves, nematodes and nauplii) vs adults colonizing the sponges

Fig. 4 PCA based on taxa composition of synthetic sponges' substrata deployed in the vicinity of the Eiffel Tower edifice on the Lucky Strike vent field, Mid-Atlantic Ridge

Fig. 5 DistLM and dbRDA showing the effect of environmental variables on faunal taxa composition. The position from fluid emission explained significantly (66\%) the differences in taxa composition. 

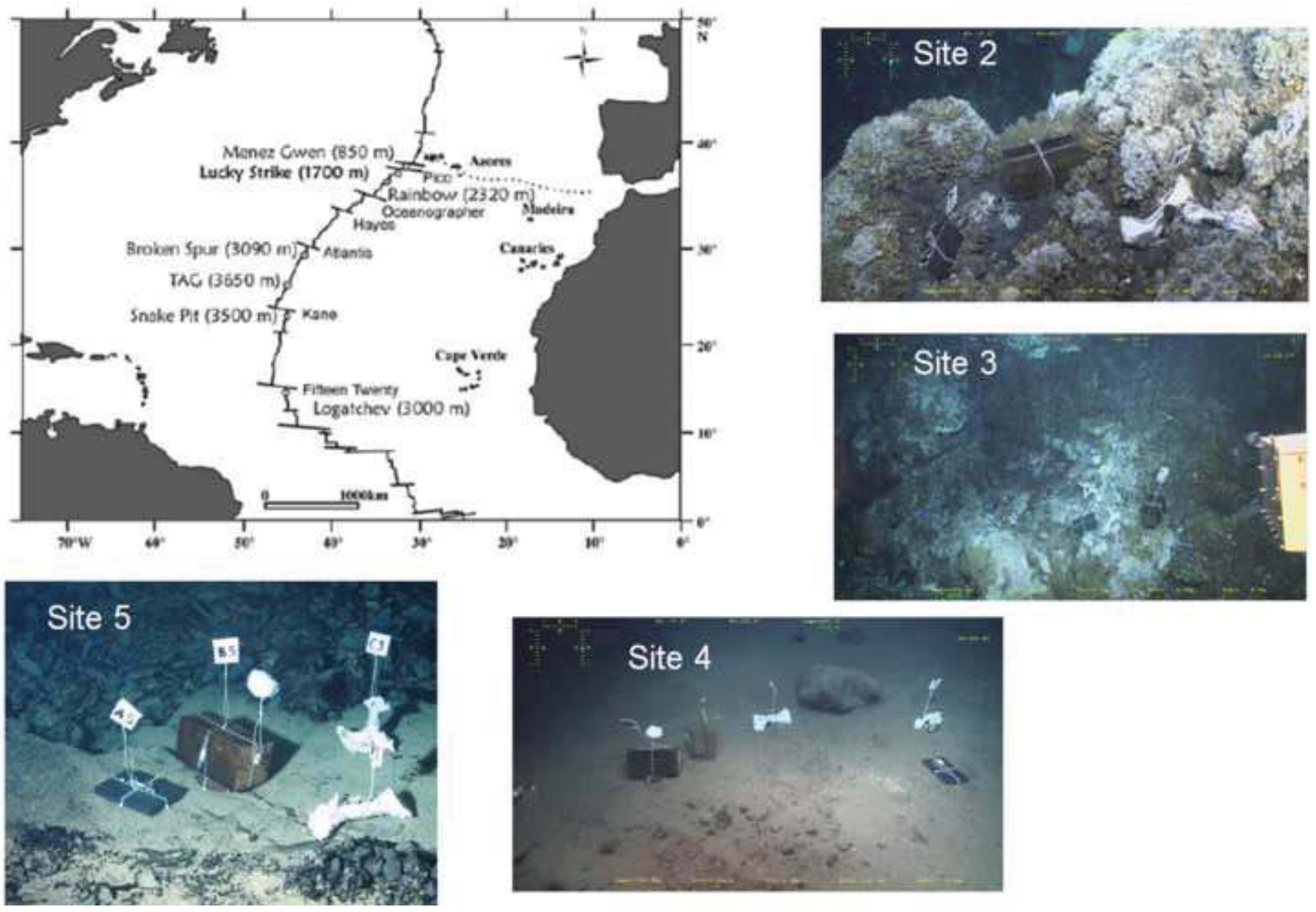


\section{口Meiofauna $\square$ Macrofauna}

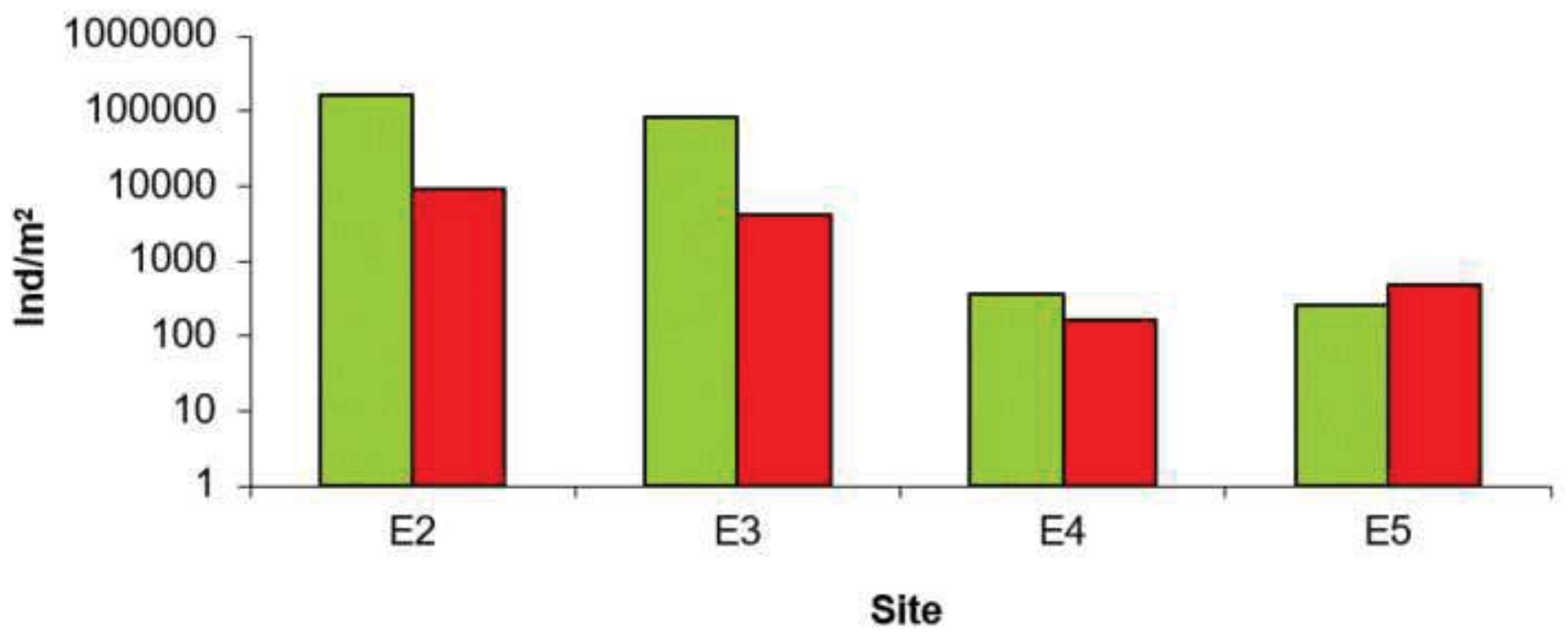


A

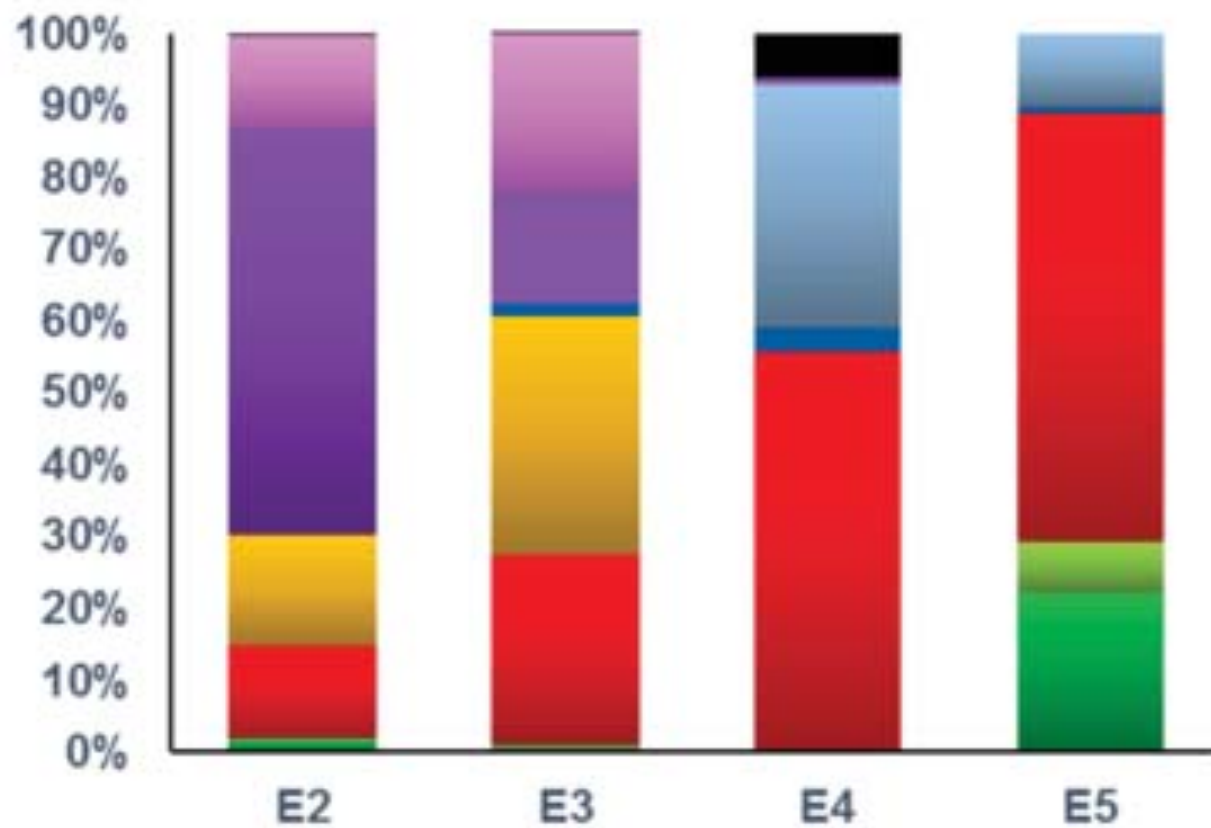

-Others

= Nematoda juveniles

nematoda

a Bivalvia larvae

- Mollusca

ఐNauplii

- Crustacea

ఐ Polychaeta larvae

- Polychaeta

E2

E3

E4

E5

B

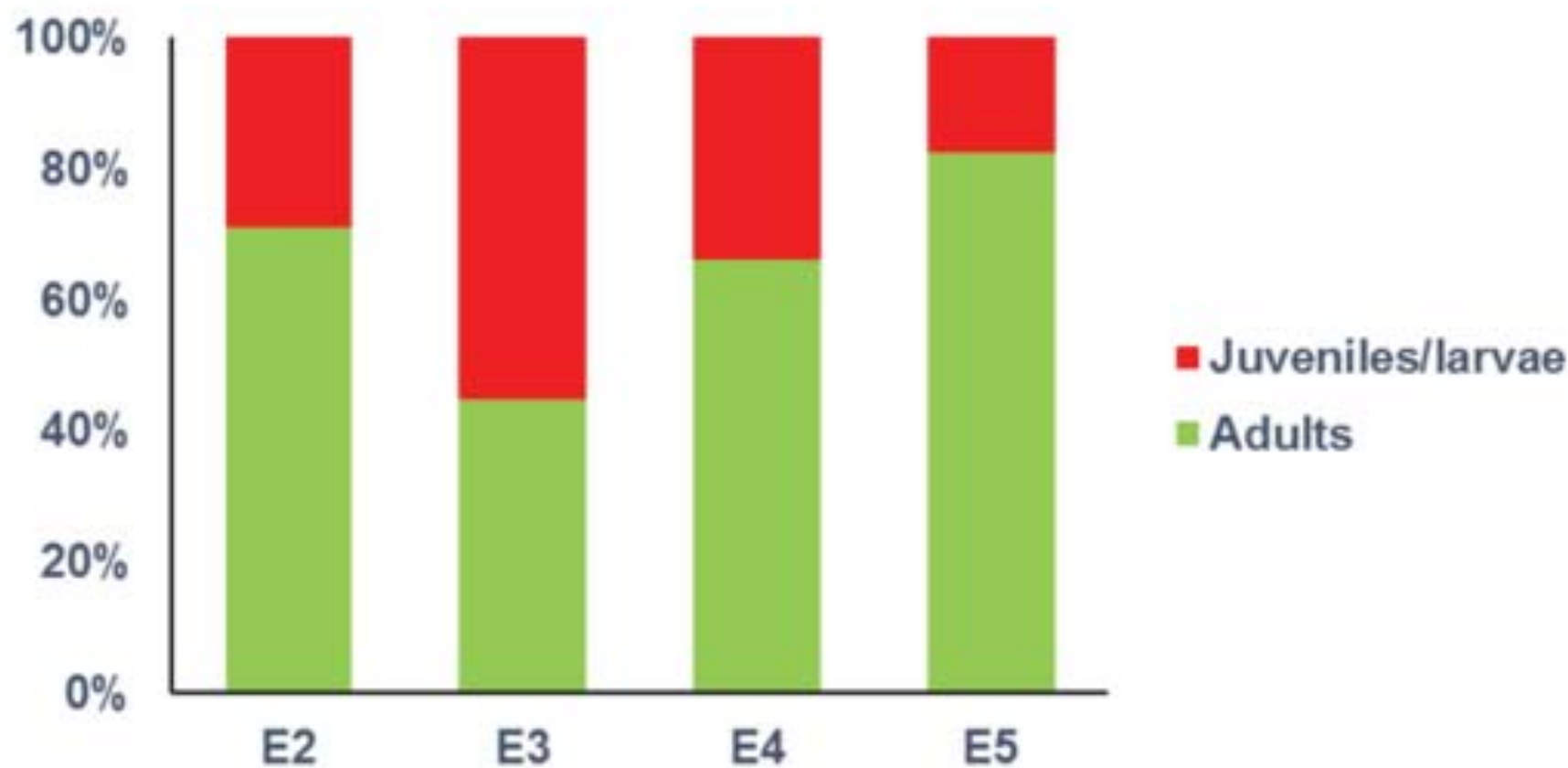




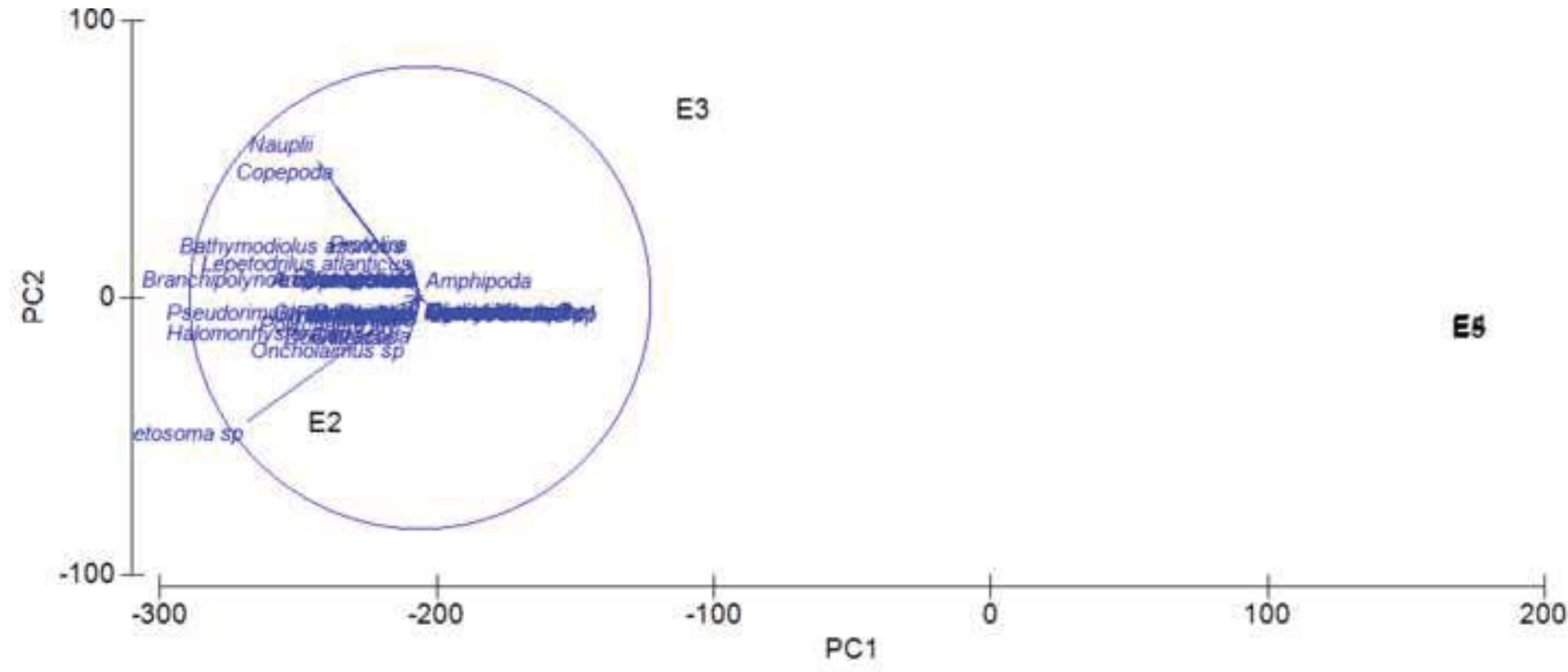




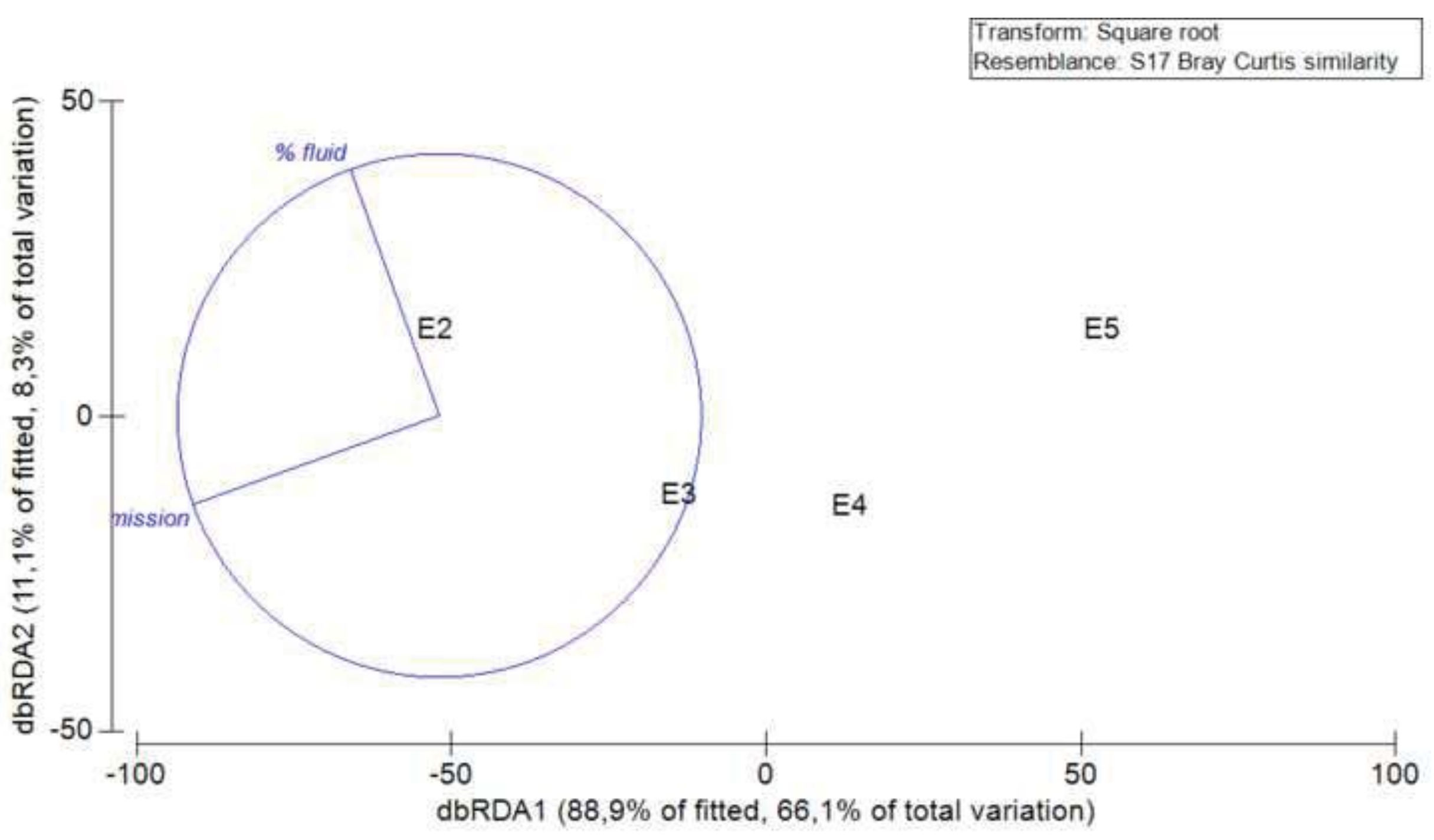

